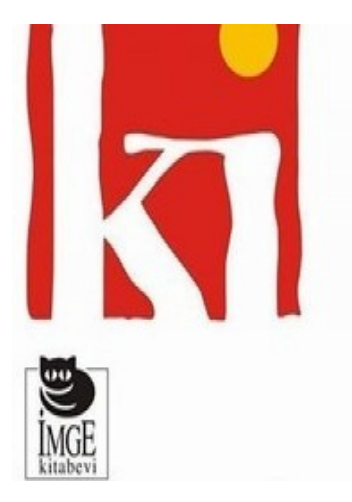

\author{
Kültür ve İletişim \\ culture\&communication \\ Yıl: 22 Sayı: 44 (Year: 22 Issue: 44) \\ Eylül 2019-Şubat 2020 (September 2019-February 2020) \\ E-ISSN: 2149-9098
}

Araştırma Makalesi

\title{
Metalaşmış Feminizm Kadınları Güçlendirir mi? 8 Mart Dünya Emekçi Kadınlar Günü Reklamlarının Feminist Eleştirel Söylem Analizi*
}

\begin{abstract}
Gülüm Şener*
Öz

Türkiye'de şirketler, hem feminist hareketlerin daha görünür olması hem de kadınların işgücüne daha fazla katılmalarına bağlı olarak alım güçlerinin artmasıyla birlikte, toplumsal cinsiyet eşitliği konularında daha fazla çaba gösterir ve reklam kampanyalarında kadınların toplumsal konumlarını destekleyici ve güçlendirici mesajlara ağıllık verir hale geldiler. Kadınların reklamlarda temsilleri de zaman içerisinde dönüşüme uğradı; daha önceleri edilgen, seksi, anaç, fedakâr gibi ataerkil kadın temsillerinin yerini günümüz reklamlarında aktif, güçlü, bedeniyle barışık, özgüveni yüksek, ekonomik güce sahip, kendi hayatını kendi yöneten kadın temsilleri almaya başladı. Ancak, piyasa ekonomisi ve tüketim kültürüyle hemhal şirket feminizminin kadın hakları mücadelesine ne denli katkı sunduğu tartışmalı bir konu. Reklamlarda karşımıza çıkan "güçlü kadın" söyleminin nasıl inşa edildiği incelenmeyi hak ediyor. Bu çalışmanın savı, şirket feminizminin feminist mücadeleyi metalaştırdığı ve günümüz reklamlarında sunulan "güçlü kadın" temsillerinin kadınlardan ziyade marka imajını güçlendirmeyi amaçladığıdır. Çalışma, Türkiye'de çeşitli firmaların 8 Mart Dünya Emekçi Kadınlar Günü için hazırladıkları reklam filmlerini feminist bir perspektifle, eleştirel söylem analizi aracılığıyla inceleyerek, şirketlerin kadınların güçlendirilmesine ilişkin hangi söylemsel stratejileri kullandıklarını ve söylemlerinin feminist mücadeleyle ne kadar uyumlu olduğunu ortaya koymayı amaçlıyor. Toplumsal cinsiyet rollerine ilişkin kalıpyargılara karşı çıkan metinler olarak incelenen filmlerin bazılarında, yüzeysel bir feminizm sunulduğu bazılarında ise kalıpyargılara karşı çıkılır gibi görülürken aslında geleneksel rollerin yeniden üretildiği görülüyor.
\end{abstract}

Anahtar Sözcükler: Feminizm, reklam, metalaşma, neoliberalizm, 8 Mart.

\footnotetext{
* Geliş tarihi: 20/05/2019 • Kabul tarihi: 26/08/2019

** 15 Kasım Kıbrıs Üniversitesi İletişim Fakültesi, Yeni Medya Bölümü

Orcid no: 0000-0002-8625-0304, gulumsener@gmail.com
} 


\title{
Can Commodified Feminism Empower Women? \\ Feminist Critical Discourse Analysis of International Working Women's Day Advertisements*
}

\author{
Gülüm Şener
}

\begin{abstract}
In recent years, companies have become more involved in gender equality issues for two main reasons: the influence of the feminist struggle and the critics towards the objectification of women bodies in advertising, and the increasing purchasing power of women due to their greater participation in labour force. Companies focusing on advertising campaigns that support and empower women's positions in social life. Thus, the representation of women in commercials has changed over time; whereas women were previously portrayed as passive, sexy, maternal, devoted; they are represented as active, strong, self-confident and selfdirected in today's commercials. However, the contribution of corporate feminism to the struggle for women's rights is a controversial issue, as it is based on the liberal market economy's values and consumer culture. The discourse of "powerful woman" in advertisements deserves to be examined. The thesis of this study is that corporate feminism commodifies feminist struggle, and the representations of 'strong women' in today's advertisements aim to strengthen brand image rather than women's. This study aims to reveal discursive strategies of Turkish TV commercials of various companies, broadcasted on the $8^{\text {th }}$ of March, 2019, the International Working Women's Day, using feminist critical discourse analysis. As a result, it is found that, while some commercials include superficial feminist messages, some others reproduce traditional gender roles while pretend to challenge stereotypes.
\end{abstract}

Keywords: Feminism, advertisement, commodification, neoliberalism, 8th March.

\footnotetext{
${ }^{*}$ Received: 20/05/2019 • Accepted: 26/08/2019

** 15 Kasım Kıbrıs University The Faculty of Communication, Department of New Media

Orcid id: 0000-0002-8625-0304, gulumsener@gmail.com
} 


\section{Metalaşmış Feminizm Kadınları Güçlendirir mi? 8 Mart Dünya Emekçi Kadınlar Günü Reklamlarının Feminist Eleştirel Söylem Analizi}

Günümüzde kapitalizm artık kadınların yalnızca bedenlerini değil, onların mücadelesini de metalaştırarak kâr elde ediyor. Şirketler hem feminist mücadelenin etkisiyle hem de kadınların iş gücüne daha fazla katılmalarına bağlı olarak alım güçlerinin artmasıyla birlikte toplumsal cinsiyet eşitliği konularında daha fazla çaba gösterir ve reklam kampanyalarında kadınların toplumsal konumlarını destekleyici ve güçlendirici mesajlara ağırlık verir hale geldiler. Kadınların reklamlarda temsilleri de zaman içerisinde dönüşüme uğradı; daha önceleri edilgen, seksi, anaç, fedakâr gibi ataerkil kadın temsillerinin yerini günümüz reklamlarında aktif, güçlü, bedeniyle barışık, özgüveni yüksek, ekonomik güce sahip, kendi hayatını kendi yöneten kadın temsilleri almaya başladı. Ancak, piyasa ekonomisi ve tüketim kültürüyle hemhal şirket feminizminin kadın hakları mücadelesine ne denli katkı sunduğu tartışmalı bir konu olarak önümüzde duruyor. "Metalaşmış feminizm", "üçüncü dalga feminizmi”, "post-modern feminizm”, "popüler feminizm” gibi farklı adlarla kavramsallaştırılan ve eleştirilen bu olgu, çalışmanın merkezinde yer alıyor.

Bu çalışmanın temel savı şirket feminizminin feminist mücadeleyi metalaştırdığı ve günümüz reklamlarında sunulan "güçlü kadın” temsillerinin kadınlardan ziyade marka imajını güçlendirmeyi amaçladığıdır. Çalışmanın amacı, günümüz reklamlarında metalaşmış feminizmin öne çıkan belli başlı söylemlerini belirlemektir. Bu söylemleri tespit edebilmek için "güçlü kadın" imgesinin en çok görünür olduğu 8 Mart Dünya Emekçi Kadınlar Günü seçildi ve Türkiye'de 8 Mart 2019'da hem televizyonda yayınlanan hem de sosyal medyada dolaşıma giren popüler markaların reklam filmleri incelendi. Araştırmada yanıt aranan başlıca sorular şunlar: Şirketler, reklam filmlerinde kadınlara dair ne gibi güçlendirici mesajlar veriyorlar? "Güçlü kadın" imgesi hangi kavramlarla inşa ediliyor? Reklam filmleri, geleneksel toplumsal cinsiyet rollerini yıkmaya mı yoksa onları başka biçimlerde yeniden üretmeye mi yarıyor? Çalışmada eleştirel söylem analizi feminist bir perspektiften yorumlanıyor. 
Eleştirel söylem analizi, söylemsel pratikler, olaylar ve metinler ile daha geniş toplumsal ve kültürel yapılar, ilişkiler ve süreçler arasındaki açık ya da örtük nedensellikleri araştırır (Durna ve Kubilay, 2010:59). van Dijk'ın eleştirel söylem analizi, feminist eleştirel söylem analizi yöntemine feminist bir duyarlılık ilave edilerek sürdürülmektedir (Nas, 2015:18). Michelle M. Lazar’a göre "Feminist eleştirel söylem çalışmalarının amacı, sık sık kabul edilen cinsiyete dayalı varsayımların ve hegemonik iktidar ilişkilerinin farklı bağlamlarda ve topluluklarda söylemsel olarak üretildiği, sürdürüldüğü, müzakere edildiği ve meydan okunduğu karmaşık, ince ve bazen de ince olmayan yöntemlerin gösterilmesidir" (2007:142). Feminist eleştirel söylem analizinin; cinsiyet, iktidar ve ideolojinin söylemdeki ilişkisini açığa çıkarmayı ve ataerkil bir toplumsal düzeni sürdüren, kadınları sosyal bir grup olarak dezavantajlı kılan, dışlayan ve rahatsız eden iktidar ilişkilerine ilişkin söylemleri eleştirmeyi hedeflediğini belirten Lazar, çok katmanlı bir analiz öneriyor ve metinlerde kullanılan dilin yanı sıra görüntüler, sesler, jestler gibi diğer semiyotik unsurların da incelenmesi gerektiğinin altını çiziyor (2007:144-149).

Lazar'ın sunduğu bu perspektifi benimseyen çalışmada analiz için örneklem belirlenirken öncelikle internette "8 Mart 2019 Kadınlar Günü reklamları" taraması yapıldı ve en çok sayıda reklamı arşivleyen (99 reklam) MediaCat Dergisinin internet sitesine ulaşıldı. ${ }^{1}$ Reklamlar incelenerek markaların "güçlü kadın” imgesi oluşturmada hangi temaları kullandıkları ve stratejileri izledikleri tespit edildi. Sonrasında amaçlı örneklem yöntemiyle her bir stratejiyi temsil ettiği düşünülen ve tanınırlığı yüksek birer marka analiz için seçildi. Aşağıda öncelikle reklamlarda yer alan metalaşmış feminizm kavramına ilişkin kuramsal tartışmalar ele alınacak, ardından 8 Mart Dünya Emekçi Kadınlar Günü reklamlarının analizine geçilecektir.

\section{Metalaşmış Feminizm}

Günümüzde reklamlarda güçlü kadın temsillerinin artmasının arkasında ne gibi etkenler yatıyor olabilir? ABD'de reklamlarda kadın temsillerine yönelik eleştirilerin İkinci Dalga Feminizm'le ve özellikle Betty Friedan'ın The Feminine Mystique (1963) kitabıyla başladığını hatırlatan Steve Craig, 1970'ler boyunca reklam endüstrisinin

\footnotetext{
${ }_{1}$ Bkz. https://mediacat.com/8-mart-dunya-kadinlar-gunu-kampanyalari-2019/ (Erişim tarihi: 08.03.2019)
} 
kadını nesneleştiren temsillerinin feministlerce eleştirildiğini ve reklamcıların uygulamalarını gözden geçirerek kadın odaklı pazarlama stratejilerine yöneldiklerini hatırlatıyor (1997:13). Reklamlarda kadınların temsili üzerine yapılan birçok araştırma; ürün ve hizmetlerin satışını artırmak için kadın bedeninin "cinsel nesne"/“arzu nesnesi” olarak kullanıldığını ve idealleştirildiğini (Batı, 2010: 103; Adalı Aydın, 2014: 58; Güdekli ve Çelik, 2014), kadınların sınılı ve geleneksel rollerle (ev kadını, anne, eş vb.) genellikle özel alanda, erkeklerin ise kamusal alanda resmedildiğini (Bal, 2014; Şenkal, 2016: 91), erkek karakterlere güç ve tahakküm pozisyonu atfedilirken kadın karakterlerin "güzel”, "duygusal”, "boyun eğen”, "mantık dışı” özelliklerle tanımlandıklarını (Çankaya, 2013: 293) ve medyanın toplumsal cinsiyet kalıplarını yeniden ürettiğini ortaya koyuyor. Son yıllarda ise reklamlarda genç kadınların, erkek bakışının edilgen nesneleri olmak yerine; aktif, bağımsız ve cinsel açıdan güçlü biçimde temsil edildiğini belirten Rosalind Gill'e göre bu değişen temsilin arkasında yatan en güçlü iki neden; kadınların giderek artan ekonomik bağımsızlığı sonucunda yeni ürünlerin hedef kitlesi haline gelmeleri ve 1980'lerin sonu-1990'ların başından itibaren reklamcıların, kadınları nesneleştirmeleri ve idealleştirilmiş kadınlık temsilleri sunmaları nedeniyle kadınların öfkesine maruz kalarak kadın tüketiciler için mesajlarını ve temsillerini gözden geçirmeleridir (2008: 35-39). Nike, Dove, Barbie ve daha birçok küresel marka bir süredir kadınları ve kız çocukları güçlendiren reklam kampanyalarıyla toplumsal cinsiyet kalıplarına karşı çıkıyorlar. 2019'da İngiltere'de Reklam Standartları Kurumu (ASA) cinsiyetçi mesajlar içeren reklamların yasaklanacağını duyurdu (bianet.org, 2019). İngilizce'de femvertising (feminist advertising-feminist reklamcılık) terimi feminist mesajlar içeren reklamlar için kullanılıyor ve ABD'nin New York kentinde 2015'ten bu yana her yıl toplumsal cinsiyet rollerine meydan okuyan markalara SHE Media tarafından Femvertising Ödülleri veriliyor. ${ }^{2}$ Elisa Becker-Herby'e göre feminist reklamlar beş temel unsur içeriyorlar:

1- Çeşitli kadın yetenekleri kullanmak, 2- Özü itibarıyla kadını destekleyen mesajlar içermek, 3- Cinsiyet normlarına dair sınırları/yargı kalıplarını zorlamak ve bir kadın/kızın "ne olması gerektiğine" dair algılara meydan

2 Bkz. https://www.femvertisingawards.com/, 16.05.2009. 
okumak, 4- Cinselliğin önemsizleştirilmesi (özellikle erkek bakışına uymayan cinselliğin), 5- Kadınları otantik biçimde tasvir etmek (BeckerHerby, 2016:19, akt. Hunt, 2017: 27).

Feminizm temalı ve/ya kadın hakları savunuculuğu yapan reklam kampanyaları neden eleştiriliyor? Şirketlerin kadın hakları savunuculuğuna katkıda bulunmalarında ne gibi bir sorun olabilir? Tüketici kapitalizmin yeniden üretilmesinde ve kapitalist hegemonyanın korunmasında önemli rol oynayan, yeni bir sembolik ortamda tüketimi, medyayı, politikayı, düşünce ve davranış biçimlerini ve içeriğini şekillendiren ayrıcalıklı bir söylem haline gelen (Harms ve Kellner, 1991) reklam metinleri, kadın hakları mücadelesini şirket-merkezli popüler ve ana akım anlatılarla çerçeveleyerek hem ürün ve hizmetlerin pazarlanmasını hem de neoliberal ideolojinin değerlerinin medya tüketicilerine aktarılmasını sağlıyor. Yalnızca feminizmin değil, daha genel olarak toplumsal değişimi arzulayan diğer sosyal hareketlerin de popüler kültür ve reklam anlatısı tarafından emilmesi eylemciliğin (aktivizmin) de metalaşmasına yol açıyor. Çünkü neoliberal düzende meta aktivizmi, toplumsal eylemin pazarlanan bir meta olarak fetişleştirilmesiyle birlikte yeni bir "gösterge değeri" yaratıyor (BanetWeiser ve Mukherjee, 2012: 13). Sarah Banet-Weiser meta feminizmini şöyle tanımlıyor:

Meta feminizmi, Robert Goldman, Deborah Heath ve Sharon L. Smith tarafından geliştirildiği haliyle, 20. yüzyılın sonlarında, ticari amaçlar için feminist simgelerin ve ideallerin benimsenmesi yoluyla (öncelikle kadın) yorgun, müstehzi ve medyaya aşina izlerkitleyi cezbetmeye çalışan bir reklam stratejisidir. Burada Marx'ın meta fetişizminin bir uzantısı olarak, feminist ideolojiler ve uygulamalar siyasi değerlerinden ve anlamlarından boşaltılarak tüketicilere meta olarak sunulurlar (Banet-Weiser, 2012: 46).

Katherine B. Marcus Reker de feminist reklam kampanyalarının aktivizmi metalaştırdığını ve feminist içerikli ürünleri satın almanın sistematik cinsiyet ayrımcılığına dayalı modern siyasi iklimde tüketicinin kendi kendini terapi etmesinden öteye gitmediğini savunuyor (2016: 2-3). Metalaşmış feminizmin, şirketlerin toplumsal cinsiyet ayrımcılığına karşı çıkan çevrimiçi feminizme ve kadınları güçlendirme hareketlerine dayanarak geliştirdikleri bir reklam stratejisi, kapitalist bir çözüm olduğunu belirten Reker, neoliberalizmin kendine yeterli ve kendini yöneten bireyler yarattığını, buna uygun şekilde kadınların reklamlarda daha güçlü, bağımsız ve 
kendini gerçekleştiren bireyler olarak resmedildiklerini ve özgüvenin metalaştırıldığını söylüyor (2016: 7-12). Julie E. Dowsett de metalaşmış feminizmin güncel feminist siyasetle ve kadınların yaşam koşullarıyla ilgili çok az şey içerdiğini hatırlatarak, onun neoliberal öznellikler yaratarak radikal hayal gücünü sınırladığını ve feminist bilinci bastırmaya yaradığını ileri sürüyor. Dowset'e göre metalaşmış feminizm, "Kadınları sadece toplumsal ve politik sorunlardan uzaklaştırmakla kalmaz, aynı zamanda meta üretimi ve eril kapitalist sosyal ilişki tarafından zorunlu kılınan özel bir kadın öznelliği biçimi de yaratır” (2010: 2). Benzer şekilde Lazar da günümüzde reklamlarda popüler kültür ve medya endüstrilerinden kaynaklanan tüketici odaklı bir popüler "postfeminist" söylemin egemen olduğuna işaret ediyor. Lazar'a göre post-feminist reklamlarda iki temel unsur göze çarpıyor: Birincisi, kadınların cinsel arzusunun yeniden kazanılması ve cinsel eylemin kutlanması. İkincisi ise güç ilişkilerinin tersine çevrildiği bir dünyanın varlığı. Post-feminist reklamcılık; kadınların güçsüzleştiğini ve ezildiğini söyleyen ataerkil toplumsal cinsiyet ideolojilerinin modasının geçtiğine ve dünyanın hızla güç ilişkilerinin kadınlar lehine değiştiği bir kadınlar dünyasına dönüştüğüne inanıyor (Lazar, 2007: 157-159). Alyssa Baxter, şirketlerin bu tür postfeminist reklamlarla "sahte aktivizm" yaptığını ileri sürerek erkeklere yönelik reklamlarda geleneksel toplumsal cinsiyet rollerinin devam ettiğini hatırlatıyor (2015: 49). Baxter'in bu savıyla uyumlu bir şekilde, iki binin üzerinde reklam filmini inceleyen Craig, prime time kuşağında yayınlanan reklamlarda kadın temsillerinin geleneksel toplumsal cinsiyet rollerini yıktığını, gündüz kuşağında yayınlanan reklamlarınsa geleneksel rollerin temsilini sürdürdüğünü tespit etmiştir (1992: 9). Şirketler feminist eğilimleri marka kimliğine taşıyarak, onları sosyal sorumluluk kampanyalarının bir parçası olarak ve satışların sürdürülür olması için de kullanıyorlar (Erbaş, 2018: 82). Maria L. Carreon da reklamlarda öne çıkan "güçlü ve seksi kadın" imgesinin ve söyleminin kadın haklarını garantilemediğini, şirketlerin kadınların yaşamını etkileyen politikalar üzerinde gerçek bir etkiye sahip olmaktan ziyade, satışı yapılan ürünlerle daha fazla ilgili olan "saçma" bir güçlendirme söylemine vurgu yaptıklarını ifade ediyor:

Reklam verenlerin ve kapitalistlerin, kadınların güçlendirilmesiyle ilgili terimleri ve tanımları kontrol etmelerine izin vermek bizi, aksi takdirde politik bir hareket olarak sahip olabileceğimiz gerçek yetkilendirmelerden 
mahrum bıraktı. Feminizmin amaçlarına dikkat etmeliyiz... Ve feminizm nosyonunu, bireysel değerimizin kapitalist nosyonlarını reddederken, doğası gereği tüm insanlar için üreme özgürlüğü, ücret paritesi ve sosyal adalet gerektiren bir eylemci duruşu da politik bir konum olarak benimsemeliyiz (2017: 4-5).

Michelle Lazar ve Cheris Kramarae'ye göre, Sex and the City ve Bridget Jones gibi küresel TV dizileri ve filmleri bir tür "post-feminist ethos"a yol açıyorlar ve bu bakış açısı feminist, feminist olmayan ve feminizm karşıtı unsurları aynı anda içererek toplumsal ve politik güç/güçlendirme meselelerini bulandırıyor, feminist eleştiriye vakit kaybettiriyor (2011: 226). Banet-Weiser da "popüler feminizm" olarak adlandırdığı bu olgunun, medya ve sosyal ağlarla görünür olan, şirket dostu, kapitalizme meydan okumaktan ziyade ona katkıda bulunan neoliberal bir feminizm türü olduğunun altını çiziyor (2018: 20-24). Ona göre popüler feminizm, özellikle "güçlendirme" temasını kullanarak neoliberal kültür içerisinde feminizmi yeniden inşa ediyor. Bu güçlendirmenin tam olarak ne olduğunu açıklamadan bireysel olarak güçlendirilmiş kadına odaklanıyor: "Kızlara ve kadınlara 'kendinden emin ve güçlenmiş’ olmaları söylendiğinde bu, kişisel bir tercih olarak çerçevelenir: Sadece buna inanmaları yeterlidir ve sonra öyle olurlar" (Banet-Weiser, 2018: 33). BanetWeiser’a göre, popüler kültür aracılığıyla yaygınlaşan "kendine güven” mesajı, uygun malların tüketilmesi yoluyla elde edilebilen ve böylece neoliberal kapitalist uygulamaların yaygınlaşmasını sağlayan post-feminist bir üründür (2012: 45).

"Seçme", "kendin olma" ve "kendini sevme" kavramlarının post-feminist söylemlerin merkezinde yer aldığını belirten Gill de, kadınların tüm eylemlerini özgürce seçen özerk bireyler olarak sunulmalarının neoliberalizmin arzuladığı psikolojik özneyle uyumlu olduğunu ileri sürüyor (2007: 11-12). Neoliberal feminizmin "kendine güven”, “öz-sevgi ve öz-saygı" söylemleri, cinsiyete dayalı adaletsizliklere karşı herkese uyabilecek çözümler gibi sunularak adaletsizlikleri gidermenin yolunun toplumsal ve politik dönüşümler için başkalarıyla birlikte çalışmaktan ziyade, kendi üzerine çalışmaktan, kendini değiştirmekten geçtiğini vurguluyor (Gill, 2016: 8). Eva Chen'e göre de, tek yol gösterici ilkenin pazarlama ve kişisel çıkar olduğu yeni bir öz yönetim biçimi olan neoliberalizm, bireyleri kendi çıkarlarına en elverişli yolu izlemeye istekli olmaya ve özgürce seçmeye teşvik eder (2013: 443). Neoliberal özneler, pasif 
tüketiciler değil, kendi seçimlerinin üreticileri ve kendi risklerini hesaplayabilen öznelerdir. "Ayakkabı fetişizmi ya da 'alışverişkolik' davranış, artık kadınların moda endüstrisinin zulmü tarafından mağdur edildiğinin bir kanıtı değildir; aksine güvenin ve bireysel kimliğin inşasının kaynağı olarak görülmektedir” (Chen, 2013: 444).

Christina Scharff ise konuya başka bir boyut getirerek tüketim gücüne sahip, orta sınıf, güçlenmiş, kendi kendini yöneten, ahlaki açıdan üstün neoliberal kadın öznelerin kimliklerinin kırılgan, güçsüz, pasif ve bağımlı "öteki” kadınlara karşı kurulduğunu ve bu nedenle sınıfsal ve ırksal ayrımcılıkların yeniden üretildiğini belirtiyor (2014). Günümüz reklamlarında üretilen çağdaş kadın mitinin fiziksel olarak aktif, çok boyutlu, otoriter, meydan okuyan, cesur, eğlenceli, başarı odaklı ve durdurulamaz kadın temsilleri üzerine kurulu olduğunu belirten Nermin Alkan, bu reklamlarda kullanılan kadını güçlendirme retoriğinin aslında kadınların bağımsızlıklarının ve dişil güçlerinin bir işareti olarak önerilen markaları tüketmelerini teşvik etmeye yaradığını ileri sürüyor (2016: 119). Benzer şekilde Pelin Aktaş da reklamlarda yer alan "güçlü ve özgür kadın" temsillerinin kadınların cinsiyetle ve güzellikle ilişkilendirilen sunumlarını değiştirmediğini, markaların ürün ve hizmetleri pazarlamak için "yeni güzellik" ve "kadınlık" anlayışı yarattıklarını söylüyor (2018: 99). Özetle, bu yazarlara göre, günümüz reklamlarında liberal anlatılara eklemlenen feminist söylemler kapitalizmin değerlerini meşrulaştırma işlevi görüyor.

Feminist mesajlar içeren reklamlara olumlu yaklaşan yazarlar da vardır. Bu yazarların ortak düşüncesi, feminizmin popüler kültür aracılığıyla görünürlük kazanması ve şirketleri kadınların hak taleplerine kulak vermeye zorlamasıdır. Bu görüşe sahip yazarlara göre, kadınlar reklamlar aracılığıyla feminist retoriği benimsiyor, tüketimle ve iyi tasarlanmış kampanyalarla kendilerini güçlenmiş hissediyor (Hunt, 2017:26). Örneğin Lisa Dahlbeck Jalakas, tüketim kültürünün ve kültürel üretimin kadınların güçlenmesi için alan sağladığını, bunun yalnızca bireysel değil, kolektif ve politik bir olgu olduğunu belirtiyor (2016: 15). Post-feminizmi, günümüzün toplumsal bağlamına uygun yeni bir güçlendirme veya öznellik biçimi olarak kavramsallaştıran Fien Adriaens ve Sophie Bauwel de bu yeni feminizmin unsurlarının özgürlük, cinsel zevk, moda, tüketim kültürü, melezlik, mizah ve kadın bedeni üzerindeki odağın bir yenilenmesi olduğunu belirtiyorlar: "Sex and the City, kadınların hem kadınsı ve çekici hem de feminist olabilecekleri bir dünyayı gösteren 
post-feminist bir kültürel üründür" (2011: 18). Bu sava göre feminizm ile kapitalist tüketim kültürü birbiriyle çelişen değil, iç içe geçen unsurlar olarak görülebilir. Jenny Coleman'a göre post-feminizmle birlikte "feminist" politika kişisel bir tarz veya kişisel tercih meselesi haline gelmiştir ve örgütlülüğe yapılan herhangi bir vurgu, saf, hatta kadınlara baskı anlamına gelmektedir (2009:7). Elif Cihangiroğlu ise, femvertising reklamlarıyla kadınların güçlü, ayakları üstünde durabilen, kusurlarına rağmen güzel ve doğal olarak temsil edilerek artık ayrımcılığa maruz kalmadıklarını ileri sürer (2018: 13). Toplumsal cinsiyet rollerine meydan okuyan reklamların kadın izleyicilerce nasıl alımlandığını inceleyen ve Çiğdem Başfırıncı, Büşra Ergül ve Behiye Özgüden tarafından yapılan araştırma, kadınları kanıksanmış rollerin dışında sergileyen reklamların farkındalık yaratma amacına ulaştığını, ama toplumsal cinsiyete yönelik yerleşik algıların da hala güçlü olduğunu bulguluyor (2018: 211).

\section{Mart Dünya Emekçi Kadınlar Günü Reklam Filmlerinde “Güçlü Kadın" İmgesi}

Çalışma kapsamında incelenen reklamlarda idealleştirilmiş "güçlü kadın" temsillerinin altı tematik başlıkta toplandığı görüldü: tüketici kimliğiyle "güçlenen" kadın, özgüvenli kadın, çalışma hayatında yer alan aktif kadın, ön yargıları yıkan mücadeleci kadın, bireysel aktivist kadın, toplumsal cinsiyet rollerini tersine çeviren kadın. Her temayı en iyi yansıtan reklam seçilerek bu filmler çok katmanlı bir analizle (hikâye, kadın temsilleri, yazılı ve sözlü metin, dış ses, ses ve müzik kullanımı, mekân ve genel atmosfer) incelendi. Bu reklamların içerdiği "güçlü kadın" mitinin ve feminist mesajların neoliberal değerler üzerine kurulu reklam retoriğiyle (tüketim, rekabet, bireysellik vb.) nasıl örtüştüğü ortaya konmaya çalışıldı.

\section{Tüketici Kimliğiyle “Güçlenen” Kadın}

A101 Marketlerinin reklam filminde (57 saniye), firmanın 7 Mart'ta yaptığı kadınlara yönelik indirim kampanyası tanıtılıyor (mediacat.com, 2019a). Son yıllarda birçok markanın 8 Mart'ta indirim kampanyaları düzenlemesi kamuoyunda tartışmalara neden oluyor, şirketler emekçi kadınların gününü tüketim gününe dönüştürmekle eleştiriliyorlar. Her Perşembe günü belirli ürünlerde indirim kampanyası yapan A101 
markası, 8 Mart arifesinde kadınlara fırsat ürünleri sunarak emekçi kadınlar gününü tüketim gününe çeviriyor. A101 markasının reklam filmi "8 Mart Dünya Kadın Gününüz Kutlu Olsun!” yazısıyla açılıyor. Kadın dış ses, indirime giren ürünleri tek tek tanıtırken görüntüde ürünler, fiyatları, tarih ve firmanın logosu ile sloganı yer alıyor. İlk tanıtılan ürün olan saksı çiçekleri ekrana geldiğinde dış ses, alaycı bir tonda “Yalnız ‘\#kadınlarçiçekdeğil, çiçekler çiçektir’ diyenlere saksısında taptaze orkide 24 lira 95 kuruş." diyor. Buradaki alaycı dış ses, bir yandan ataerkil reklam anlatılarında sıkça rastlanan "Kadınlar çiçektir" sloganına karşı çıkarak feminist bir mesaj verirken diğer yandan kadınlar gününde kadınlara çiçek alınarak kutlama yapılması mesajını vererek bir çelişki içeriyor. Daha sonra "Çok yönlü hanımlara müjde!" denilerek tanıtımı yapılan çok amaçı dolap, fincan ve kaselerdeki indirim hakkında bilgi veriliyor. Reklam filminin bu bölümünde hitap edilen kadınların ev kadını olduğu ve ev kadınlığının "çok yönlülük" ve "hanım” sözcükleriyle tarif edildiği anlaşılıyor. Bu bölümde kadınların geleneksel rollere uygun olarak ev içi emekle ve özellikle mutfakla ilişkilendirildiği görülüyor. Son olarak dış ses, şımarık bir tonla "Şekerim, bakım benim için her şeyden olmasa da birçok şeyden önce gelir." diyor ve görüntüye L'Oréal bakım kremleri, Marie Claire kil maskesi ve fiyatları giriyor. Bu kısım, kozmetik reklamlarında sıkça karşılaştığımız kadınların toplum içinde dış görünüşleri üzerinden değer kazandıkları mesajını yeniden üretmeye hizmet ediyor. Reklam filmi, dış sesin "Tüm kadınların Dünya Kadınlar Günü Kutlu Olsun” cümlesiyle sonlanıyor.

Görüldüğü üzere, bu reklam filminde bir yandan feminist mesajlar verilirken diğer yandan toplumsal cinsiyet rollerine ilişkin geleneksel mesajlar tekrarlanıyor. Reklamda seslenilen neoliberal kadın özne, tüketici kimliğiyle öne çıkarılıyor ve 8 Mart, markaların kendisine sunduğu fırsatlar ve avantajlar arasından özgürce seçim yapabileceği ve hediyeleri kabul edeceği bir tüketim gününe dönüştürülüyor. Makalenin önceki başlığında belirtildiği gibi, neoliberal düzende tüketim kültürü, kadınların mücadele etmesi gereken bir unsur değil, aksine güvenin ve bireysel kimliğin inşasının kaynağı olarak görülüyor (Chen, 2013: 444). Kozmetik markalarının 8 Mart reklamlarını göstergebilimsel açıdan inceleyen Mehmet Erhan Summak ve Yeliz Öztürk de markaların eşitlik ve emek ruhuna sahip bu özel günü, kâr elde 
etmek için indirim, puan, sürpriz hediyeler sunarak tüketilebilir hale getirdiğini belirtiyorlar (2018: 123).

\section{Özgüvenli Kadın}

Giyim markası De Facto'nun 8 Mart için hazırladığı \#DuruşunYeter sloganını taşıyan reklam filminde (35 saniye), markanın reklam yüzü ünlü oyuncu Aslı Enver ile De Facto giyinen genç kadın oyuncular rol alıyorlar (mediacat.com, 2019b). Pop müzik eşliğinde Aslı Enver'i ve genç kadınları tek tek veya grup halinde farklı mekânlarda kameraya doğru bakıp gülümserken izliyoruz. Kadınlar mutlu, kendine güvenli, şık ve bakımlı olarak resmediliyorlar. Kamera, önce kadınları daha çok omuz ve bel plan çekerek, içinde bulundukları mekândan ziyade yüzlerine odaklanmamıza yol açıyor. Ardından birkaç kadını bir ofiste konuşurken, bir kadını sınıfta ders anlatırken, bir diğer kadını aynada makyaj yaparken, bir grup genç kadını sohbet ederken izliyoruz. Her sahnede kadınlar, bulundukları ortamdan, yaptıkları işlerden ve kendilerinden memnun ve mutlu görünüyorlar. Genç kadınlar için rol model olarak sunulan Aslı Enver, aynı zamanda reklam filmini seslendiriyor ve "Varlığın Yeter", "Sözlerin Yeter", "Renklerin Yeter”, "Gülüşün Yeter” diyerek kadınlara cesaret aşılıyor. Son olarak tüm kadınlar aynı mekânda bir araya gelerek "Duruşun Yeter" yazısı önünde poz veriyorlar. Film, markanın logosunun altında yer alan "Dünya Kadınlar Günü Kutlu Olsun" mesajıyla sonlanıyor. De Facto reklam filmi sadece kadın olmanın bile mutlu olmak için yeterli bir neden olduğu fikrinden yola çıkarak kadınlığı olumluyor, bunu yaparken kadınların yaşadığı sorunları görünmez kılarak onlara bireysel tercihleri ve görünümleri üzerinden bir tüketici kimliği sunuyor. Genç kadınların kendilerini güzel, şık, mutlu, özgüvenli hissetmeleri De Facto giyiyor olmalarıyla ilişkilendiriliyor. Ayrıca, reklam filminde markanın hedeflediği kitle olarak yalnızca orta sınıf ve üzeri, muhafazakâr ve seküler genç kadın temsillerine yer veriliyor ve diğer kadın temsilleri (işçi sınıfı, orta yaşlı, yaşlı, farklı toplumsal ve etnik kökenlerden, farklı cinsel yönelimlerden ve kimliklerden vb.) dışarıda bırakılıyor. Kadınlar kimi sahnelerde özel alanda birbirleriyle sohbet ederken veya ayna karşısında kendilerine bakım yaparken, kimi sahnelerde kamusal alanda ancak yine de kadınlara biçilen mesleklerle/rollerle resmediliyorlar. Kadınlar önce bireysel, sonra grup halinde, en sonunda da ünlü oyuncuyla bir arada görünüyorlar. "Duruşun Yeter" sloganı etrafında 
buluşan kadınlar, dik duruyorlar, kendilerinden emin bir şekilde kameraya gülümseyerek bakıyorlar. Ancak bu duruşu sağlayan en önemli unsur, ortak giyim zevkleri ve De Facto tüketicisi olmaları. Kadınlar giyimleriyle, yani dış görünümleriyle ve bu dış görünümü sağlayan giyim markasıyla mutlu, özgüvenli ve güçlü mesajı veriliyor. Bu mesaj, post-feminizmin "kendin olma" ve "kendini sevme" söylemleriyle paralellik içeriyor. Neoliberal kadın özneler, öz-saygılarını ve öz-sevgilerini ("Varlığın Yeter", "Sözlerin Yeter", "Duruşun Yeter" sloganları) De Facto tüketerek elde edebiliyorlar ve Gill'in belirttiği gibi post-feministlere göre toplumsal cinsiyete dayalı eşitsizlikler başkalarıyla birlikte çalışmaktan ziyade, artık kendi üzerine çalışmaktan (2016: 8), kendi imajını özgürce seçmekten geçiyor. Reklam filmi "Kendini seversen dünya değişir" mesajı veriyor. Reklam filminin bir yandan post-feminist söylemlerle kesiştiğini, kadınların bireyselliklerinin, tüketici kimliği üzerinden değer kazandığını; diğer yandan filmde moda endüstrisine, kadın dergilerine ve buralardaki reklamlara hâkim olan konvansiyonel güzellik ve gençlik anlayışının yinelendiğini görüyoruz.

\section{Çalışma Hayatında Yer alan Aktif Kadın}

Şirketlerin kadınları güçlendirirken reklamlarda kullandıkları stratejilerden biri de kadın emeğinin görünür kılınması. Bu çerçevede bir diğer giyim markası olan $L C$ Waikiki, 8 Mart reklam filminde (49 saniye) kendi bünyesinde çalışan 16 kadını oynatıyor, şirketin üzerinde yükseldiği emeğin kadın emeği olduğu mesajını veriyor (mediacat.com, 2019c). Erkek dış sesin "Kadının yeri” dediği ve yakın plandan çekilen farklı kadın yüzlerinin mutsuz bir ifadeyle izleyiciye dönüp baktıkları ilk sahnelerin ardından, kadınlardan biri "Kadının yeri” sözüne “LC Waikik” yanıtını vererek kameraya bakıp gülümsüyor ve çekim ölçeği genişliyor. Seyirciler, şirketin farklı düzeylerinde çalışan kadınları işlerini yaparken izlerken bu kez kadın dış ses şunları söylüyor:

Kadının yeri LC Waikikide çok değerli. Mağaza ve lojistikten, strateji ve ürün tasarımına; yönetim kurulundan, genel müdüre bin sekiz yüz kadın yöneticimiz ve yirmi beş bin kadın çalışanımızla birlikte büyüyoruz. Türkiye'de kadına en çok istihdam sağlayan şirket olmaktan gurur duyuyoruz. 
Kadınlar tek tek kameraya bakarak gülümsedikten sonra 16 kadının gülümseyen yüzleri tek bir sahnede bir araya getiriliyor ve dış sesin "Tüm kadınların Dünya Kadınlar Günü Kutlu Olsun" sözünün ardından firmanın logosu ve cıngılla reklam sona eriyor. Dış sesin erkekten kadına dönmesi, erkek dış sesin "Kadının yeri” dediği sahnelerde kullanılan gergin müziğin yerini kadınların yer aldığı sahnelerde piyano ağırlıklı, umut dolu bir müziğe bırakması sözün ve gücün artık kadınlara geçtiğine vurgu yapıyor. Reklam metni, "Kadının yeri evidir" anlayışına karşı çıkarak "Kadının yeri LC Waikiki'dir', iş yaşamıdır, ofistir, fabrikadır diyerek kadınların iş yaşamına girerek güçlendikleri mesajını veriyor. Ev içi emek/ücretli emek karşıtlığı üzerine kurulu mesajda kadınlar işveren (LC Waikiki) sayesinde daha mutlu, özgür ve üretken oluyorlar.

Neoliberal kadın özne, aktif olarak iş yaşamında yer alan, ekonomik bağımsızlığa sahip, kendi ayakları üzerinde durabilen kadın olarak, çalışma yaşamının dışında kalan ve ev içi emek harcayan diğer kadınlardan farklılaştırılarak kuruluyor. Şirketin yönetimden tasarıma; güvenlikten, çay ocağına farklı departmanlarında çalışan ve farklı yaş gruplarından ve sosyal çevrelerden gelen kadınlar mutlu, güler yüzlü, güçlü ve özgüvenli olarak temsil ediliyorlar. Çeşitliliğin vurgulanması hedef kitlenin kadınlarla daha kolay özdeşleşmesini sağlamaya yarasa da farklı koşullarda çalışan kadınların çalışma koşullarının üzerinin örtülmesini sağlıyor. Reklam filmi, aslında belki de aynı çalışma ortamını bile paylaşmayan, şirket hiyerarşisi içerisinde farklı pozisyonlarda ve maaşlarda çalışan bu kadınları aynı düzlemde bir araya getirerek sınıfsal farkların silinmesini, kadın çalışanların hak mücadelesinin görünmez kılınmasını, kadınların sınıfsal aidiyetlerinin silikleşmesini, böylece yanlış bilinç oluşturulmasını sağlıyor. Ayrıca şirket içerisinde kadın istihdamının ve büyümede kadın emeğinin rolüne ilişkin istatistikler verilerek markanın kadın emeğine ne kadar değer verdiğinin altı çiziliyor. Şirketin kalkınmasına hizmet eden mutlu kadın çalışanların yer aldığı bir fotoğraf albümü sunuluyor adeta. Bunun yanı sıra senaryo kadın emeği üzerine kurulu olmasına karşın, filmin sonunda 8 Mart, "Dünya Emekçi Kadınlar Günü” olarak değil, "Dünya Kadınlar Günü” olarak anılıyor. Reklam filminde "Capital 2017 Kadın Dostu Şirketler Araştırması'na göre Kadın Çalışan Dostu ve Kadın Yönetici Dostu” altyazısı da geçiyor. Oysa, 8 Mart 2017 tarihinde LC Waikiki depolarında ve mağazalarında 
çalışan kadın işçiler, basın açıklaması yaparak çalışma şartlarının mesleki hastalıklara yol açtığını, kadınların doğum öncesi ve sonrası şirket kaynaklı sorunlar yaşadıklarını, çocuklar için kreş hizmeti verilmediğini ve primlerini alamadıklarını belirtiyorlar (ilerihaber.org, 2019).

\section{Ön Yargıları Yıkan Mücadeleci Kadın}

"Başarının Cinsiyeti Olmaz" sloganıyla yayınlanan TEB Kadın Bankacılığı reklamı (1 dakika 11 saniye), toplumda kadınlara ilişkin sıkça karşılaştığımız ön yargıları sarsarak kadınları güçlendirmeyi hedefliyor (mediacat.com, 2019d). Kadınlara ilişkin geleneksel yargılara sahip "erkek toplumu" simgeleyen terk edilmiş eski bir depoda/fabrikada, kadın dış sesin "Biz kadınlar, iş yaşamında karşılaştığımız ön yargılardan çok daha fazlasıyla mücadele ederiz. Ama bu engelleri aşmasını da biliriz." dedikten sonra parkur atleti Hazal Nehir, tek başına, önüne çıkan engelleri çevik hareketlerle teker teker aşarak kadınların başarıya ulaşabileceğini kanıtlıyor. Atlet, görüntüde dev puntolarla "Ön yargı”, "Vazgeç”, "Bulamazsın”, "Yapamazsın”, "Olamazsın" yazılı engellerin üzerinden atlarken, fonda erkek dış seslerin kadınlara ilişkin kalıpyargıları tekrarlayarak kadının cesaretini kırmaya çalıştığını duyuyoruz: "Kadın başına olmaz o iş”, "Sana kim güvenecek?”, “Iş̧i büyütmek için parayı nereden bulacaksın?", "Kolay mı sanki öyle yurtdışına açılmak?”, "Kadından patron olmaz" (burada yalnızca erkek değil, kadın sesi de duyuluyor). Kadının iş yaşamında karşılaştığı sorunlar bu mücadele sahnesiyle ve fonda gergin, ama dinamik bir müzikle anlatılıyor. Atlet, depodan çıkarken bir kadın sesi "Olur" diyor ve oyuncuyu bir limanda, konteynırların arasında üzerinde iş kıyafetiyle, erkek bir işçinin kendisine uzattığı formu imzalarken, ardından da takım elbisesiyle TEB'e kredi almaya giderken görüyoruz. Kadın dış ses, "Ve TEB başarıya giden yolda engel tanımayan kadınların her zaman yanında durur. Çünkü başarının cinsiyeti olmaz.” derken, oyuncu, bankadan içeriye giriyor ve reklam filmi şirketin logosuyla sona eriyor.

Günümüz reklam metinlerinde sıkça karşılaşıldığı üzere bu reklam filminde de kadınların geleneksel rolleri ve kadınlara ilişkin kalıpyargılara karşı çıkılarak kadınları güçlendirme stratejisi izleniyor. Ancak, burada da kadının ekonomik güce sahip olabilmesi için erkek dünyasında çok mücadele vermesi gerektiği ve bu mücadelenin bireysel olduğu vurgulanıyor. Girişimci kadın, genç, atletik ve mücadeleci bir kadın 
olarak temsil ediliyor. Kadın, toplumsal ortamından ve diğer kadınlardan soyutlanmış bir şekilde, "bireysel becerileriyle iş hayatında erkeklerle aynı başarıyı yakalayabilir" mesajı benimsenirken, bankadan kendi işini kurması için kredi (borç) alması da bir başarı olarak kodlanıyor. Kadın hakları mücadelesi bireylerin tek başına engelleri ve ön yargıları aşarak verdiği ve yine yalnızca kadınların üzerine yüklenen bir mücadele olarak kodlanıyor. Oysa kadınlara yönelik ön yargıları aşmanın yolu, eğitim sisteminden, kadınlar ile erkeklerin toplumsal cinsiyet rollerini sorgulayacak eleştirel düşünme becerilerine sahip olmasından da geçiyor. Aslında bu reklam filminde, birçok reklam filminde gördüğümüz kapitalizmin rekabet ve "bireysel başarı"lar üzerine kurulu olduğu fikri yeniden üretiliyor. Öte yandan, kadınlara "istediğin hedefe çabalayarak ve ancak bireysel gayretlerinle ulaşabilirsin" mesajı verilirken, her kadının eşit fırsata sahip olmadığı gerçeği de göz ardı ediliyor. Kadınların ekonomik hayatta bir arada, dayanışma içerisinde üretim yapmalarından, dayanışmalarından ve güçlenmelerinden hiç söz edilmiyor, ekonomik hayata katılımın politik ve örgütlü bir mücadele içerdiğine değinilmiyor.

\section{Bireysel Aktivist Kadın}

Boyner Grup'un 8 Mart için hazırladığı reklam filminde (45 saniye) farklı sınıfsal konumlardan, yaş grubundan, mesleklerden kadınlar haklarını dile getiriyorlar (mediacat.com, 2019e): Gergin bir fon müziği eşliğinde bir ilkokul öğrencisi "Okumak hakkım!”; bir öğretmen "Okutmak hakkım!”; genç bir kadın "Eve çıkmak hakkım!”; gece eğlenmeye giden genç bir kadın "Evden çıkmak hakkım!”; oy kullanan genç bir kadın "Seçmek hakkım!"; basın toplantısı düzenleyen kadın siyasetçi "Seçilmek hakkım!"; kadın boksör "Kazanmak hakkım!”; ofis çalışanı bir kadın "Eşit kazanmak hakkım!"; orta yaşın üzerinde bir kadın evinde "Evlenmek hakkım!"; fabrika işçisi genç bir kadın "Evlenmemek hakkım!"; bir kafede sevgilisinin elini tutan engelli bir kadın "Sevmek hakkım!"; sokakta çiçek satan mülteci bir kadın Arapça "Sevilmek hakkım!" diyor. Ardından aynı kadınlar teker teker "Eşitlik" ve "Hakkım" kelimelerini söylüyorlar. Son sahnede, ilk sahnede gördüğümüz ilkokul öğrencisi "Nokta” diyor. Boyner logosu, "Toplumsal Cinsiyet Eşitliği” ve \#nokta etiketiyle film sona eriyor.

Toplumdaki kadınların çeşitliliğinin temsil edildiği reklam filminde farklı kesimlerden, yaşam tarzlarından, yaş grubundan, etnik kökenden kadınların farklı 
alanlarda karşılaştıkları ön yargılara karşı başkaldırıları öne çıkarılıyor. Diğer reklam filmlerinden farklı olarak burada herhangi bir dış ses kullanılmıyor ve kadınlar kendilerini dile getiriyorlar. Kadınlar haklarını hatırlatırken yüzleri gergin, izleyiciye bakıyorlar, kızgın ve öfkeli görünüyorlar ve fon müziği de bu gerginliği tırmandırıyor. Kadınlar, haklarını haykırarak geleneksel kalıpyargıları protesto ediyorlar. Reklam filminin sonunda kız çocuğu "Nokta" diyerek kadın haklarının tartışılamaz olduğunu belirtiyor. Bu filmde de diğer filmlerde olduğu gibi kadınlar diğer kadınlardan bağımsız, dayanışma içerisinde değil de bireysel olarak "hakkım" diyerek ve Türkiye'de hala tabu sayılan konularda (gece geç saatte evden çıkmak, seçimlerde aday olmak, geç yaşta evlenmek, okula giderek, ayrı eve çıkarak gibi) bireysel olarak eyleme geçerek haklarını savunuyorlar. Neoliberal toplum yalnızca ekonomik alanı değil, sosyal ve politik direniş biçimlerini de yeniden şekillendirerek aktivizmi metalaştırıyor ve daha büyük politik hedeflerden ziyade tüketicilerin faydalanıcıları olduğu eylem biçimleri öneriyor (Banet-Weiser ve Mukherjee, 2012: 9-11). Diğer politik aktivizm biçimleri gibi feminizm de neoliberal çağda kişisel bir tarz veya tercih meselesine dönüşüyor (Coleman, 2009:7). Reklam, her bir kadının baskılara karşı bireysel olarak mücadele vererek temel haklarını elde edebileceği düşüncesini pekiştiriyor. Oysa kadınların bahsettikleri her hakkın edinilmesinin arkasında uzun yıllara yayılan kolektif kadın mücadeleleri yer alıyor ve reklamda dile getirilen birçok hak hala tamamen kazanılmış değil. Reklam filmi, hakların kazanılması için kadınların ortak mücadelesinden ve dayanışmasının gerekliliğinden ziyade, kadınların bu haklara zaten sahip olduğunu vurguluyor.

\section{Toplumsal Cinsiyet Rollerini Tersine Çeviren Kadın}

Türkiye'de toplumsal cinsiyet eşitliği eğitimi veren ve Ekonomik İş Birliği ve Kalkınma Örgütünün (OECD’nin) Haziran 2019'da yayınlanan "Cinsiyet Eşitliği İçin Filantropi Raporu"na göre dünyada toplumsal cinsiyet eşitliğini öne çıkaran yedi vakıftan biri seçilen (sivilalan.com, 2019) Sabancı Vakfı'nın reklam filmi (44 saniye), kadınların eğitimine verdikleri desteği ele alıyor (mediacat.com, 2019f). \#EğitimHakkıTartışılmaz sloganını taşıyan filmde, iki genç bilim insanı Mars'ta yaşam üzerine bir tartışma yürütüyorlar. Açılış sahnesinde iki kadın bilim insanı, laboratuvarda bir yandan çalışıyor diğer yandan yeni gelişmelerle ilgili bilgi paylaşımı yapıyorlar: "Mars için yeni 
oval yapılar tasarlanmış, duydun mu?" Diğeri yanıt veriyor: "Demronlar mı?" "Evet." "Dış yüzeyi kalkan olanlar". Ardından iki genç kadın, bilim merkezinde üzerinde beyaz önlükleriyle yürürken, laboratuvarda deney yaparken, kütüphanede kitapları incelerken bilimsel terimlerle tartışmalarını sürdürüyorlar. Daha sonra, klasik müzik eşliğinde dış ses devreye giriyor ve bilimsel mekânlarda farklı kadın bilim insanları ve kız öğrencileri bilimle uğraşırken görüyoruz. Dış ses şunları söylüyor: "Bu devirde bunlar tartışılır. Kızlar okusun mu, okumasın mı tartışılmaz. Sabancı Vakfı Türkiye'nin dört bir yanında kadınları ve kız çocuklarını desteklemeye devam ediyor. 45 yıldır.” Reklam, vakfın logosuyla sonlanıyor.

Şüphesiz toplumsal cinsiyet eşitliğinin sağlanmasında önemli alanlardan biri de kadınların erkeklerle eşit eğitim hakkına ve olanaklarına sahip olmaları. Reklam filmi de kadınların güçlendirilmelerinde eğitimin rolünü öne çıkaran bir söylemden hareket ediyor ve eğitim hakkının tartışılamaz olduğu mesajını veriyor. Senaryo, Türkiye'de kızların okutulmaması olgusuna (bu olgunun nedenleri reklamda belirtilmiyor) meydan okuyarak, Sabancı Vakfı sayesinde kadınların ve kızların eğitim alma imkanına sahip olduklarını ve vakıf olarak donanımlı bilim insanlarını yetiştirdiklerini vurguluyor. Yurttaşların eğitim hakkından eşit bir şekilde yararlanabilmelerinin ve eğitimde fırsat eşitliğini sağlamanın devletin görevi olduğunu ileri süren sosyal devlet anlayışından ziyade, sivil toplumun ve şirketlerin devletin tamamlayıcısı olduğu neoliberal kalkınma söyleminden beslenen bu reklam metninde, vakfın kadınlar ve genç kızların eğitimi için verdiği destek anlatılıyor. Devletin yerine geçen sivil toplum kuruluşunun ulusal düzeydeki ("Türkiye'nin dört bir yanından”) desteklerinden Türkiye'de kadınların ve kız çocuklarının ne kadarı yararlanabiliyor ve ne kadarının hayatı reklamda tasvir edildiği şekilde değişebiliyor? Reklam metni, kadınların ve kız çocuklarının eğitime erişimlerinin engellenmesinde rol oynayan başlıca toplumsal kurumları, yapıları ve zihniyetlerin kimler olduğunu belirsiz bırakırken, eğitim hakkı meselesinin artık aşıldığını, vakıf sayesinde kadınların ve kız çocuklarının kaliteli eğitim aldıkları mesajını içeriyor. Türkiye için henüz ütopik sayılabilecek, ama bu yüzden de ilgi çekici olan, steril bir bilimsel ortamda geçen reklam filminde geleneksel erkek bilim insanı rolü, kadın bilim insanıyla yer değiştiriyor. Film boyunca bilimsel mekânlarda yalnızca kadınlar yer alıyor, üretiyor ve tartışıyorlar. Bu yer değiştirme ve tabu yıkma, kadınları güçlendirirken bilim dünyasını erkeksizleştirerek gerçekçilikten 
uzaklaşıyor. Türkiye'de kadınların ve kız çocukların eğitim hakkının hala tartışılabiliyor olması, bir mesele olarak önümüzde duruyor. Türkiye'de eğitimin özelleştirilmesi ve İslamileşmesi, eğitimde fırsat eşitliğinin ve toplumsal cinsiyet eşitliğinin sağlanmasının önünde iki engel olarak beliriyor. Türkiye'de yıllardır uygulanan politikalarla ve kampanyalarla kız çocuklarının okullaşma oranlarında önemli ölçüde ilerleme sağlanmış olsa da toplumsal cinsiyet eşitsizliği giderilebilmiş değil. OECD’nin “2016 Tek Bakışta Eğitim Raporu”na göre Türkiye, kız öğrencilerin eğitime katılımında diğer ülkelerle karşılaştırıldığında hala en alt sıralarda yer alıyor ve kadınların sadece \%50'sinin üniversite diplomasına sahip olduğu belirtiliyor (bbc.com, 2019). Rapor, kadınların bilim ve mühendislik gibi alanlarda yetersiz, eğitim ve sağlık gibi alanlarda ise aşırı temsil edildiğine de dikkat çekiyor. Eğitim-Sen'in “2018-2019 Eğitim-Öğretim Yılı Raporu”nda, eğitimde muhafazakâr egemen ideolojinin ve dinsel içeriklerin giderek daha fazla ağırlık kazanmaya başlamasıyla, geleneksel cinsiyet rollerinin yeniden üretildiği ve eğitim sisteminin demokratikleşmekten uzaklaştığı vurgulanıyor (eğitimsen.org.tr, 2019).

\section{Sonuç ve Değerlendirme}

Son yıllarda reklam endüstrisinin kadın haklarına ve feminist mesajlara daha çok yer verdiği aşikâr. Reklamlarda öz güvenli, güçlü, kendisiyle ve bedeniyle barışık kadın temsilleri daha fazla kullanılıyor. Ancak, bu temsillerin geleneksel toplumsal cinsiyet kalıplarını ne kadar yıkabildiği, kadınların toplumsal konumunun ve feminist hareketin gelişimine ne kadar etki ettiği ile izleyicilerin kadın haklarına bakışını ne kadar değiştirdiği tartışmalı. Yukarıda da bahsedildiği gibi, yapılan araştırmalar, reklam filmlerinin feminist mesajlar içermelerinin, kadın haklarına ilişkin çeşitli sorunları görünür kılmaya ve izleyenler için bir tartışma zemini hazırlamaya bir ölçüde hizmet etse de markanın imajının güçlendirilmesine ve alım gücüne sahip kadınların markayla bağ kurarak onun tüketicisine dönüşmelerine daha çok yaradığını kanıtlıyor. Tüketim kültüründe reklamlar, feminizmi alınıp satılabilen bir metaya, bir trende dönüştürmekle kalmıyor, aynı zamanda neoliberal kadın özneler üretilmesini sağlıyor. İncelenen reklam anlatılarında neoliberal kadın özneler, tüketim kültürüyle barışık, tüketerek "güç kazanan" ve "kendisi olan", özgüveni yüksek, çalışma hayatında yer alan, aktif, ön yargıları yıkmak için bireysel olarak mücadele eden, 
toplumsal dayanışmadan ziyade bireysel aktivizmi benimseyen, toplumsal cinsiyet rollerini tersine çeviren "güçlü" kadınlar olarak tarif ediliyor.

İncelenen reklam filmlerinin hiçbirinde 8 Mart, "Dünya Emekçi Kadınlar Günü” olarak kutlanmıyor. Kadın emeğini öne çıkaran LC Waikiki reklamında bile "emek" sözcüğü yer almıyor. Oysa, 8 Mart'ın 1857 yılında ABD’nin New York kentinde grev yapılan bir tekstil fabrikasında çıkan yangınla hayatını kaybeden 129 kadın işçiyi anma günü olduğu biliniyor. Markalar, işçi sınıfının emek mücadelesini anma günü olan “Dünya Emekçi Kadınlar Günü” yerine "Kadınlar Günü” gibi sınıfa referans yapmayan daha geniş bir terimi kullanmayı tercih ediyor, böylece bu göstergenin içini neoliberal değerlerle (tüketim, bireysellik, rekabet vb.) yeniden doldurabiliyorlar.

Şirketler çoğunlukla 8 Mart gibi kadın haklarına duyarlılığın yüksek olduğu bir günde feminist mesajları reklam kampanyalarına dahil ederken diğer günlerde kadınları nesneleştiren reklamlar üretmeye de devam edebiliyorlar. Örneğin, kadın bedenini idealleştirdiği için yoğun eleştiriler alan Barbie markası, bir yandan toplumsal cinsiyete ilişkin kalıpyargıları yıkmaya yönelik reklam kampanyaları ${ }^{3}$ düzenlerken diğer yandan cinsiyetçi kalıpları yeniden üretebiliyor (Tatar, 2016). Bu açıdan, feminizm doğru zamanda doğru hedef kitleye yönelik kullanılması gereken bir pazarlama stratejisine indirgenmiş oluyor. İncelenen markaların farklı reklam kampanyalarına bakıldığında cinsiyetçi kalıpların geri dönüşüne tanık olmak mümkün. Örneğin, De Facto markası “Aslı Enver'le Elbise Mevsimi” (youtube.com, 2019a) reklam filminde, genç kadınların De Facto elbiseleriyle diğer insanlarda hayranlık uyandıracaklarını ("Sana bayılacaklar” reklam cıngılı) vurgularken; LC Waikikinin 2019 Yaz Sezonu reklamında (youtube.com, 2019b) konvansiyonel güzellik anlayışına uygun modelleri kullanıyor, Elçin Sangu'nun reklam yüzü olarak yer aldığı \#NerdenNerdenNerden (youtube.com, 2019c) isimli Boyner reklam filmi ise "kadınlar arası rekabet ve kıskançlık" gibi klişe bir konuyu anlatıyor.

Reklam filmlerinde temsil edilen "güçlü kadın" imgesi biraz deşildiğinde altında ataerkil düşüncenin izlerine de rastlanabiliyor. A101 markasının indirim

\footnotetext{
${ }^{3}$ Yıllarca Batı-merkezli güzellik anlayışını (sarışın, mavi gözlü, zayıf, uzun boylu, ulaşılması imkansız beden ölçülerine sahip kadın) evrenselleştiren ve toplumsal cinsiyet eşitsizliğini yeniden üreten Barbie, 2000'li yıllardan itibaren gelen eleştiriler doğrultusunda toplumdaki çeşitliliğe yer vermek için çeşitli kampanyalar düzenledi, bebek ürünlerini çeşitlendirdi (farklı etnik ve dini gruplardan, farklı fiziksel özelliklere sahip bebekler). Firma 2015 'ten bu yana Sheroes kampanyasıly kendi alanında başarılı olan kadınların bebeklerini üreterek kız çocuklarına ilham oluyor. Bkz. https://barbie.mattel.com/en-us/about/role-models.html
} 
kampanyasında hem feminist mesajlara yer veriliyor hem de kadınların ev içi ve tüketimle ilişkilendirilen geleneksel rolleri yeniden üretiliyor. Benzer şekilde De Facto reklam kampanyası bir yandan kadınlara "kendin ol" diyerek güven aşılarken diğer yandan konvansiyonel güzellik anlayışını yeniden üretiyor. Kadınlar birçok reklamda hala görünümleriyle ve bedensel özellikleriyle ön plana çıkarılıyorlar. Kadınlar feminist hareketten mesajlar içeren reklamlarda dahi hala cinsiyetçi biçimde temsil ediliyorlar, arzu nesnesi veya 'seyirlik nesne' olarak sunuluyorlar, eşitlik talebi için 'erkeksileştiriliyorlar' (İnceoğlu ve Onaylı-Şengül, 2018: 35). Reklamı yapılan markaları tüketerek güzelleşen, güçlenen, gülümseyerek kameraya bakan kadınların temsil edilme biçimleri "erkek bakışı"ndan ne kadar azade? Ayrıca, reklamlarda kadının gücü çoğunlukla satın alma gücüne, tüketici kimliğine indirgeniyor. İncelenen reklamlarda kadınların gücü, tüketici kimliklerinden (A101 reklamı), bireysel özelliklerinden (De Facto reklamı), bireysel çabalarından ve mücadelelerinden (TEB, LC Waikiki reklamı) geliyor ve kadın haklarının kazanımı bireysel çabalarla ilişkilendirilerek (Boyner reklamı) politik ve kolektif mücadelenin gereksinimine değinilmiyor. Reklamlarda tabular hızla yıkılıyor, toplumsal roller tersine çevriliyor (Sabancı Vakfı reklamı), sihirli bir değnek değmişçesine kadınlar özgürleşiyor. Tabu yıkıcı mesajlar içeren bu reklamlar, kadınlara yönelik önyargıların yıkılmasında kadınların bireysel sorumluluğu olduğu ve bireysel olarak mücadele ederek toplumsal cinsiyet rollerini tersine çevirebilecekleri mesajlarını taşıyorlar. Reklamlarda feminist mücadeleye emek veren isimler yerine genellikle bireysel olarak başarı kazanan kadınlar temsil ediliyor, kadın haklarının kazanılmasının arkasında uzun süren mücadele göz ardı ediliyor. Ayrıca, Sezen Yılmaz, Pelin Boğa ve Selin Top'un da belirttiği gibi güçlü kadın imajının pazarlandığı reklamlarda cinsiyet ayrımcılığının failleri ya da nedenine yer verilmiyor ve ataerki soyutlanıyor: "Bağlamından koparılan ve suya sabuna dokunmayan bir eşitlik (kurtuluş değil) dillendirilip, verili toplumsal cinsiyet rollerinin anlamsız olduğu söyleniyor.” (2018). Kadını güçlendirme iddiasında olan bu reklamlar, ataerkiye ve kadınlara yönelik ayrımcılık üreten toplumsal yapıların nasıl değiştirilebileceğine dair pek az şey söylüyorlar. Benzer şekilde, hükümete ve politikalarına da hiç gönderme yapılmıyor, sorunların kaynağı gösterilmiyor ve kadınlar kendi bireysel güçleriyle çalışarak toplumsal sorunları aşabilirlermiş gibi sunuluyorlar. Neoliberal feminist reklam anlatılarına göre toplumsal cinsiyet eşitliğine 
giden yol, her kadının toplumda farklı alanlarda kadınlara yönelik yargılara karşı bireysel mücadelesinden geçiyor ve ataerkil yapılara karşı kolektif feminist mücadele göz ardı ediliyor.

Reklamlar aynı zamanda kadınların sınıfsal aidiyetlerini silikleştiriyor. Özellikle işçi sınıfından kadınlara ya hiç yer vermiyor ya da $L C W$ reklam filmindeki gibi diğer sınıftan kadınların yanında yer veriliyor. İş yaşamında farklı pozisyonlarda olan ve aralarında hiyerarşi bulunan kadınlar, tek bir sahnede bir araya getirilerek eşitleniyor ve böylece dikkatler sınıfsal farklııklardan kadın meselesine kayıyor. Diğer yandan kadınlar hangi sınıftan olursa olsunlar hepsi eşit fırsatlara sahipmiş gibi, istediklerinde ve gayret ettiklerinde başarılı olabilecekleri mesajı veriliyor. Incelenen reklam filmlerinde kadınlar tek bir rolle temsil ediliyorlar: çalışan kadın, öğrenci, ev kadını vs. Oysa, kadınların çoğu, ev işi, iş hayatı, çocuk bakımı, yaşlı bakımı ve diğer işler arasında mekik dokuyorlar, eşitsiz iş bölümüne ve emek sömürüsüne maruz kalıyorlar.

Kadın hakları savunuculuğu mesajları içeren reklam metinleri, kadınların sorunlarını yüzeysel ve stereotipleşmiş biçimde görünür kıllıp popülerleştiriyor ve daha geniş kitlelere aktarımasını sağlıyor. Ancak aynı zamanda, yukarıda da görüldüğü gibi, bu reklam metinlerinde çoğunlukla feminist mesajlar neoliberal değerlerle birlikte harmanlanıyor, ataerkil sistemi ve kurumlarını değiştirecek köklü çözüm önerilerinden ziyade markanın sosyal sorumluluk imajına katkıda bulunan mesajlar veriliyor ve özellikle dijjtal kültür ve sosyal ağların etkisiyle taleplerini dile getiren kadınlara ürün ve hizmetlerini pazarlamak için onların dili yakalanmaya çalışılıyor. Bu nedenle, bu reklam filmlerini "feminist" olarak nitelendirmekten ziyade "feminizmi araçsallaştıran, metalaştıran reklamlar" olarak adlandırmak daha doğru olacaktır. Şirket kaynaklı feminist reklam kampanyaları, feminist özneler üretmekten ziyade neoliberal öznellikler üretmeye yarıyorlar. 


\section{Kaynakça}

Adalı Aydın, Gülten (2014). "Reklamlarda Beden Temsilleri Üzerine Karşılaştırmalı Bir İnceleme: Cosmopolitan ve Ala Dergileri Örneği." Akdeniz İletişim. 22: 4159.

Adriaens, Fien ve Sophie van Bauwel (2011). "Sex and the City: A Postfeminist Point of View? Or How Popular Culture Functions asa Channel for Feminist Discourse." The Journal of Popular Culture. 47(1): 1-22.

Aktaş, Pelin Ügümü (2018). "Toplumsal Cinsiyete Dair Değişimlerin Reklamlara Yansıması: Kadınlara Yönelik Reklamlara Göstergebilimsel Bir Bakış." Stratejik ve Sosyal Araştırmalar Dergisi. 2(3): 87-101.

Alkan, Nermin (2016). "New Trends in The Representation of Women in Contemporary Media Culture: A Critical Analysis of Three Women Empowering Advertising Campaigns." IIleti-ş-im. 24: 119-143.

Bal, Sevil (2014). "Reklamların Eskimeyen Yüzü: "Muhteşem Annelik." ilef dergi. 1(2): 59-85.

Banet-Weiser, Sarah (2012). "Free Self-Esteem Tools?": Brand Culture, Gender, and the Dove Real Beauty Campaign." Commodity Activism. Roopali Mukherjee \& Sarah Banet-Weiser (ed.). New York: New York University Press. 39-56.

Banet-Weiser, Sarah (2018). Empowered: Popular Feminism and Popular Misogyny.

Durham: Duke University Press.

Banet-Weiser, Sarah ve Roopali Mukherjee (2012). "Introduction: Commodity

Activism in Neoliberal Times." Commodity Activism. Roopali Mukherjee \& Sarah Banet-Weiser (ed.). New York: New York University Press. 1-22.

Başfırıncı, Çiğdem, Büşra Ergül ve Behiye Özgüden (2018). "İzleyici Gözünden

Toplumsal Cinsiyete Meydan Okuyan Reklamlar." UiiiD-IJEAS. (20):199-216

Batı, Uğur (2010). "Reklamcılıkta Retorik Bir Unsur Olarak Kadın Bedeni Temsilleri." Kültür ve Iletişim. 13(1): 103-134.

Baxter, Alyssa (2015). "Faux Activism in Recent Female-Empowering Advertising." Elon Journal of Undergraduate Research in Communications. 6(1): 3. http://www.inquiriesjournal.com/articles/1133/2/faux-activism-in-recent-femaleempowering-advertising

BBC (2016). "OECD Eğitim Endeksi: Türkiye sondan dördüncü sırada." 
https://www.bbc.com/turkce/haberler-dunya-37779042, Erişim tarihi:

23.06.2019.

Bianet (2019). “Ingiltere cinsiyetçi reklamları yasakladı”, Erişim tarihi: 25 Haziran

2019. https://m.bianet.org/kadin/toplumsal-cinsiyet/209732-ingiltere-cinsiyetcireklamlari-yasakladi,

Carreon, Maria L. (2017). "By Beauty Damned: Millennial Feminism and the

Exploitation of Women's Empowerment in Pop Culture and Corporate Advertising." CUNY Academic Works.

https://academicworks.cuny.edu/gc_etds/1921

Chen, Eva (2013). “Neoliberalism and popular women's culture: Rethinking choice, freedom and agency." European Journal of Cultural Studies. 16(4): 440-452.

Cihangiroğlu, Elif (2018). "Reklamlarda Toplumsal Cinsiyet Açısından Kadın

Temsilleri ve Femvertising Kavramı." İstanbul Ticaret Üniversitesi Dış Ticaret Enstitüsü Tartışma Metinleri.

Coleman, Jenny (2009). "An Introduction to Feminisms in a Postfeminist Age."

Women's Studies Journal. 23(2): 3-13.

Craig, Steve (1997). "Madison Avenue versus The Feminine Mystique: How the

Advertising Industry Responded to the Onset of the Modern Women'

Movement.” Bildiri. Popular Culture Association Konferansı. San Antonio, Teksas. 27 Mart.

Çankaya, Mine (2013). "Traditional? Modern? Or Both? Representation of Gender in Turkish TV Commercials." SDÜ Fen Edebiyat Fakültesi Sosyal Bilimler Dergisi. 30: 279-295.

Dahlbeck Jalakas, Lisa (2016). The ambivalence of \#femvertising: Exploring the meeting between feminism and advertising through the audience lens. MA Thesis. Lund University. https://lup.lub.lu.se/studentpapers/search/publication/8872529 DOI: 10.1177/0959353507084950 Donovan, Jennifer (2016). Feminist Teori. Çev., Aksu Bora, Fevziye Sayılan ve Meltem Ağduk Gevrek. İstanbul: İletişim Yayınları.

Dowsett, Julie. E. (2010). "Commodity Feminism and the Unilever Corporation: Or, How the Corporate Imagination Appropriates Feminism." Affinities: A Journal of Radical Theory, Culture, and Action, 4(2): 9-16. 
Eğitim-Sen (2019). 2018-2019 Eğitim-Öğretim Yılı Raporu.

http://egitimsen.org.tr/2018-2019-egitim-ogretim-yilinda-egitimin-durumuraporu/, Erişim tarihi: 13.06.2019.

Erbaş, Sefa (2018). “Varolmanın Dayanılmaz Zorluğu: Kadın Olmak.” LAÜ Sosyal Bilimler Dergisi. (IX-I): 75-88.

Friedan, Betty (1963). The Feminine Mystique. New York: Norton.

Gill, Rosalind (2007). "Postfeminist media culture: elements of sensibility." European Journal of Cultural Studies. 10(2): 147-166.

Gill, Rosalind (2008). "Empowerment/Sexism: Figuring Female Sexual Agency in Contemporary Advertising." Feminism \& Psychology. 18(1): 35-60.

Gill, Rosalind (2016). "Post-postfeminism? New feminist visibilities in postfeminist times." Feminist Media Studies, DOI: 10.1080/14680777.2016.1193293

Güdekli, İsmail Aysad ve İbrahim Çelik (2014). "Using Woman In Advertisement As A Symbol Of Sex: Cosmopolitan Magazine Example." Journal of Yasar University. 35(9): 6129-6137.

Harms, John ve Douglas Kellner (1991). "Toward a Critical Theory of Advertising." Current Perspectives in Social Theory, 11: 41-67 https://pages.gseis.ucla.edu/faculty/kellner/llumina\%20Folder/kell6.htm Erişim tarihi: 03.06.2019

Hunt, Alexandra Rae (2017). Selling Empowerment: A Critical Analysis of Femvertising." Senior Communication Honours Thesis, Dr. Michael Serazio. http://hdl.handle.net/2345/bc-ir:107483

İleri Haber (2017). "LC Waikiki çalışanlarından 8 Mart açıklaması." https://ilerihaber.org/icerik/lc-waikiki-calisanlarindan-8-mart-aciklamasi68990.html. Erişim tarihi: 26.04.2019.

İnceoğlu, İrem ve Gamze Onaylı-Şengül (2018). "Bir Femvertising Örneği Olarak Nike Bizi Böyle Bilin Reklam Filmine Eleştirel Bakış." Halkla Ilişsiler ve Reklam Çalışmaları E-Dergisi. 1(2): 20-36.

Lazar, Michelle M. (2007). "Feminist Critical Discourse Analysis: Articulating a Feminist Discourse Praxis." Critical Discourse Studies. 4(2): 141-164. 
Lazar, Michelle M. ve Cheris Kramarae (2011). "Gender and power in discourse." Discourse Studies: A Multidisciplinary Introduction. Teun A. Van Dijk (ed.). London: Sage. 217-240.

MediaCat (2019). "Markalardan 8 Mart Dünya Kadınlar Günü Mesajı”. https://mediacat.com/8-mart-dunya-kadinlar-gunu-kampanyalari-2019/ . Erişim tarihi: 24.04.2019.

MediaCat (2019a). "A101 Aldın Aldın”. https://mediacat.com/8-mart-dunya-kadinlar-gunu-kampanyalari-2019/3/. Erişim tarihi: 24.04.2019.

MediaCat (2019b). "De Facto \#DuruşunYeter”. https://mediacat.com/8-mart-dunya-kadinlar-gunu-kampanyalari-2019/2/. Erişim tarihi: 24.04.2019.

MediaCat (2019c). "LC Waikiki". https://mediacat.com/8-mart-dunya-kadinlar-gunu-kampanyalari-2019/2/. Erişim tarihi: 24.04.2019.

MediaCat (2019d). "\#Başarının Cinsiyeti Olmaz".

https://mediacat.com/8-mart-dunya-kadinlar-gunu-kampanyalari-2019/2/. Erişim tarihi: 24.04.2019.

MediaCat (2019e). "Boyner Grup - 8 Mart 2019 Kampanya Filmi”.

https://mediacat.com/8-mart-dunya-kadinlar-gunu-kampanyalari-2019/2/. Erişim tarihi: 24.04.2019.

MediaCat (2019f). "Sabancı Vakfı \#EğitimHakkıTartışılmaz”.

https://mediacat.com/8-mart-dunya-kadinlar-gunu-kampanyalari-2019/2/. Erişim tarihi: 24.04.2019.

Nas, Alparslan (2015). "Kadına Yönelik Simgesel Şiddet Aracı Olarak Temizlik Ürünleri Reklamlarının Eleştirel Analizi.” Akdeniz Üniversitesi Illetişim Fakültesi Dergisi. 24: 11-30.

Reker, Katherine B. Marcus (2016). “Why Can’t Run ‘Like a Girl’ Also Mean Win The Race?: Commodity Feminism and Participatory Branding as Forms of SelfTherapy in the Neoliberal Advertising Space." Scripps Senior Theses. Paper 759. http://scholarship.claremont.edu/scripps_theses/759 
Scharff, Christina (2014). "Gender and Neoliberalism: Exploring the Exclusions and Contours of Neoliberal Subjectivities."

https://www.theoryculturesociety.org/christina-scharff-on-gender-andneoliberalism/ Erişim tarihi: 04.04.2019.

Sivil Alan (2019). "Sabancı Vakfı Cinsiyet Eşitliği Çalışmalarıyla Dünya Liginde." https://sivilalan.com/2019/06/13/sabanci-vakfi-cinsiyet-esitligi-calismalariyladunya-liginde/, Erişim tarihi: 23.06.2019.

Summak, Mehmet Erhan ve Yeliz Öztürk (2018). "Kozmetik reklamlarının 8 Mart Dünya Emekçi Kadınlar Günü Reklam Mesajlarının Göstergebilimsel Analizi.” Sosyal ve Beşeri Bilimler Araştırmaları. Tahsin Tapar, Selahattin Avşaroğlu, Emel Arslan ve Mustafa Kılınç (der.) içinde.

https://www.researchgate.net/profile/Kahraman_Kalyoncu/publication/32842922 9_sosyal-ve-beseri-bilimler-arastirmalari2018/links/5bcdd25592851cae21b930c4/sosyal-ve-beseri-bilimler-arastirmalari2018.pdf

Şenkal, Yelda (2016). "Feminist Kuramlar Bağlamında Reklamda Kadın İmgesine Bakış." ABMYO Dergisi. 42: 91-114.

Tatar, Dilara Buket (2016). “Modernleşmeden Postmodernleşmeye Barbie”. Hacettepe HDF. 6(1): 167-192. http://www.hukukdergi.hacettepe.edu.tr/dergi/C6S1makale7.pdf Yılmaz, Sezen, Pelin Boğa ve Selin Top (2018). "Pazarlama stratejisi olarak feminizm." https://catlakzemin.com/pazarlama-stratejisi-olarak-feminizm/ Erişim tarihi: 23.04.2019.

Youtube (2019a). “Aslı Enver De Facto Reklamı. Aslı Enver'le Elbise Mevsimi.” https://www.youtube.com/watch?v=cbrxgKPpIDA, Erişim tarihi: 08.08.2019. Youtube (2019b). "LCW Yeni Sezon Reklamı 2019." https://www.youtube.com/watch?v=ZRmAlnFhof8, Erişim tarihi: 08.08.2019. Youtube (2019c). "Boyner Elçin Sangu Reklam Filmi." https://www.youtube.com/watch?v=nWvq0Rrr6m8, Erişim tarihi: 08.08.2019 